\title{
ESTABLISHING NEW OMBUDSMAN INSTITUTIONS - THE RIGHT STEP IN THE DEVELOPMENT OF HUMAN RIGHTS? POLISH EXAMPLE
}

\section{СТВОРЕННЯ НОВИХ ІНСТИТУТІВ ОМБУДСМЕНА - ПРАВИЛЬНИЙ КРОК У РОЗВИТКУ ПРАВ ЛЮДИНИ? ПРИКЛАД ПОЛЬЩІ}

The article indicates that the establishment of new ombudsman institutions need not necessarily contribute to increasing the protection of human rights. Very often, newly established Ombudsman institutions do not have many powers typical of classic Ombudsman organs. They are also very often associated with the executive. Creating an ombudsman dependent on the executive power significantly limits the possibilities of its operation.

The ombudsman institutions were not always combined with the protection of human rights. This is obvious, if only because of the fact that these institutions are older than the concepts of human rights protection. The ombudsman was granted the function of protecting human rights as a result of the development of these institutions and their introduction in subsequent countries, often as a result of the democratic changes of the 20th century (Portugal, Spain, Central and Eastern Europe and others); the same Ombudsman institutions were given a different feature than the one that originally connected with them in the countries in which they were established (Sweden, Scandinavian countries).

The article discusses the Polish institution of the Ombudsman for Small and Medium-sized Enterprises. It was indicated that the Ombudsman for Small and Medium Enterprises is not a classical ombudsman. He is very similar to the executive ombudsman. It is not an independent body; there are also links between the Ombudsman and the executive. The lack of independence is evidenced by the method of appointing the Ombudsman (by the Prime Minister at the request of the minister competent for economy, the manner of appointing the Deputy and the procedure for establishing the Bureau Statute. This is very important, because lack of independence may affect the actions of Ombudsman for Small and Medium-sized Entrepreneurs: he may, for example, refuse to undertake certain types of matters; may refuse to lodge a specific type of legal remedy.

Key words: the Ombudsman, the Ombudsman for Small and Medium-sized Entrepreneurs, human rights.

У статті зазначено, що створення нових інститутів омбудсмена не обов'язково має сприяти підвищенню захисту прав людини. Дуже часто новостворені установи Омбудсмана не мають багатьох повноважень, характерних для класичних органів Омбудсмана. Вони також дуже часто асоціюються з органами виконавчої влади. Створення омбудсмена, залежного від виконавчої влади, істотно обмежує можливості його діяльності.

Інституції омбудсмена не завжди поєднувалися із захистом прав людини. Це очевидно, хоча б через те, що ці інститути старші за поняття захисту прав людини. Омбудсмену було надано функцію захисту прав людини внаслідок розвитку цих інститутів та їх впровадження в наступні країни, часто внаслідок демократичних змін XX століття (Португалія, Іспанія, Центральна та Східна Європа та інші); ті ж установи Омбудсмена мали іншу особливість, ніж та, яка спочатку була пов'язана з ними в країнах, в яких вони були створені (Швеція, скандинавські країни).

У статті йдеться про польський інститут омбудсмена для малого та середнього бізнесу. Було зазначено, що Омбудсмен малого та середнього бізнесу не $\epsilon$ класичним омбудсменом. Він дуже схожий на виконавчого омбудсмена. Це не незалежний орган; також існують зв'язки між Омбудсменом та виконавчою владою. Про відсутність незалежності свідчить спосіб призначення омбудсмена (прем’єр-міністром на вимогу міністра, що відповідає за питання економіки, спосіб призначення заступника та порядок створення статуту бюро. Це дуже важливо, оскільки відсутність незалежності може вплинути на дії Омбудсмана для малих та середніх підприємців: він може, наприклад, відмовитись від певних питань, може відмовити в поданні певного виду юридичних засобів захисту.

Ключові слова: омбудсмен, омбудсмен для малих та середніх підприємщів, права людини.

Currently, in many countries there is a tendency to create new specialized ombudsmen. The Polish example shows that this is not always good practice for protecting human rights. These new ombudsman institutions do not have many of the features that the classic ombudsman possessed. First of all, these new ombudsmen are not independent. In this text I will indicate that the lack of independence may negatively affect the role of the Ombudsman in the sphere of human rights protection.

Ombudsman (or more broadly: ombudsman institution) is an entity appearing in different 
countries, having different legal status and different competences. In Poland, it has been assumed that the ombudsman (called Rzecznik Praw Obywatelskich), safeguards human and citizen freedoms and rights - hence is an ombudsman for human rights. He can be called a classical ombudsman.

The Polish ombudsman model was not created in a emtptiness; it is one of the models of ombudsman institutions that have been around the world for a long time. In the literature, such institutions have been repeatedly classified, taking into account their characteristics in various legal systems.

First of all, ombudsman institutions were not always combined with the protection of human rights. This is obvious, if only because of the fact that these institutions are older than the concepts of human rights protection. The ombudsman was granted the function of protecting human rights as a result of the development of these institutions and their introduction in subsequent countries, often as a result of the democratic changes of the 20th century (Portugal, Spain, Central and Eastern Europe and others); the same Ombudsman institutions were given a different feature than the one that originally connected with them in the countries in which they were established (Sweden, Scandinavian countries).

This point of view is the basis of the classification proposed by Linda C. Reif, who distinguished the classical ombudsman from the human rights ombudsman.

In general, she described the ombudsman not only as a certain entity, but also as a mechanism ensuring transparency of the executive power and "democratic" responsibility, which is to result in building good governance) [3, p. 2]. However, some ombudsman institutions are hybrid and deviate from this model: on the one hand it may be an ombudsman whose task is to protect human rights (human rights ombudsman), which controls the administration and at the same time performs the function of protecting human rights. On the other hand, this hybridity is expressed in entrusting the ombudsman with the function of an anti-corruption authority or in the field of environmental protection.

However, some ombudsman institutions are hybrid and deviate from this model: on the one hand it may be an ombudsman whose task is to protect human rights (human rights ombudsman), which controls the administration and at the same time performs the function of protecting human rights. On the other hand, this hybridity is expressed in entrusting the ombudsman with the function of an anti-corruption authority or in the field of environmental protection [3, p. 2].

The definition of a classic ombudsman is as follows: it is an office provided for by the constitution or by action of the legislature or parliament and headed by an independent, high-level public official who is responsible to the legislature or parliament, who receives complaints from aggrieved persons against government agencies, officials, and employees or who acts on his own motion, and who has the power to investigate, recommend corrective action, and issue reports [3, p. 3].

Classical ombudsmen typically only take complaints directed against the government and usually do not have the jurisdiction to investigate complaints between private entities [3, p. 3]. Only in some countries can the hybrid ombudsman also deal with such complaints [3, p. 3].

The characteristic feature of such an ombudsman is its independence, consideration of applications, and the right to make recommendations [1, p. 38].

As for hybrid ombudsman institutions, they are e.g. human rights commissions, ombudsman for human rights ombudsman) [3, p. 7-8] and specialized ombudsmen, such as the ombudsman for children [3, p. 8].

As indicated above, the Ombudsman for Human Rights combines the role of a classical ombudsman and an institution that protects human rights.

Regardless, the author mentioned above also distinguished the so-called executive ombudsman or quasi-ombudsman, who is appointed by the executive authorities and responsible to this power [3, p. 14].

It performs similar functions as the classic ombudsman [1, p. 38], but it is not independent. It can occur at the national, supranational and municipal levels, and their legal status varies. Undoubtedly, a characteristic feature of such an ombudsman is a relationship with the executive. It is important, however, that an executive ombudsman operating in a democratic state (e.g. UK Parliamentary Commissioner for Administration) can enjoy great independence in the performance of his functions [3, p. 14].

In the doctrine, however, there is a debate whether the executive ombudsman meets the definition of a classic ombudsman. Some question this by pointing to the lack of independence of the executive ombudsman. Others point out that formal independence from the executive is not a prerequisite for ensuring impartiality and efficiency $[3$, p. 15].

However, this division into classical and executive ombudsman is not exhaustive. Analyzing various bodies in different countries of the world, representatives of the science of law distinguished many other types of ombudsman institutions: there is also an "organizational ombudsman", which was originally established at universities and corporations, but also includes ombudsmen serving government agency employees [1, p. 39].

The Polish Ombudsman (Rzecznik Praw Obywatelskich) combines the features of a classic ombudsman, but at the same time acts as a human rights protection body. He is undoubtedly 
independent in examining complaints about public authorities - including the executive; also has certain powers, which even indirectly - affect the shape of Polish law. As reported in the literature, the ombudsman's powers in the field of judicial power may be limited, and their scope is determined by the internal law of the country [3, p. 13-14].

This Polish classical Ombudsman also has certain powers over the judiciary - however, they are limited: the Ombudsman can only take actions expressly provided for by law. It seems that in the event of any doubt as to the applicability of a given measure to the judiciary, a narrowing interpretation should apply. In addition, the Ombudsman may not violate judicial independence.

The Polish Ombudsman is a hybrid body there is no doubt that he guards the freedom and rights of human and citizen (as indicated by the Constitution of the Republic of Poland), but also his role is to ensure good administration and prevent maladministration.

Obviously, the rights of the Polish Ombudsman towards both the executive and the judiciary are important. However, the powersagainsttheexecutive are "fuller", which is also characteristic of hybrid ombudsmen in other countries where, as has already been pointed out, powers over the judiciary do not go as far as against the executive. The need for control over the administration's activities results, among others from the fact that "there is a tendency of representatives of administrative authorities to pay attention primarily to the public interest, a tendency to expand the sphere of influence of public interest in relation to the private interest and to be guided sometimes not so much by legality as under the principal guidelines of superior authorities - to achieve certain tasks in the area of the government's basic political line" [6, p. 420].

The traditional the concept of public subjective rights, created in the nineteenth century, has recently begun to be supplemented with a new element, i.e. the principle of good governance. Today, what counts is not only compliance with the entity's procedural guarantees and satisfaction within the limits set by applicable law, but also the effectiveness of actions taken by the administration, generally understood as the proper allocation of public resources (funds)" $[2$, p. 3].

Also in Polish literature some characteristic features of the Ombudsman institution are given. J. Świątkiewicz with reference to the Ombudsman [4, p. 7-8], pointed out several characteristics of the Ombudsman institution (different depending on legal regulations in specific countries):

- Informal ombudsman's proceedings (which is not guaranteed by the extensive court procedures, which require considerable costs, often using the assistance of a lawyer and characterized by lengthy proceedings).

- The Ombudsman institution complements "traditional" institutional solutions, especially in areas where there is no judicial review or where this review is limited or access is limited.

- It creates the possibility, in some countries, to challenge, within the framework of applicable procedures, even judicial decisions, or to respond to deficiencies in the non-judicial activity of courts and judges - to the extent not covered by judicial independence.

- It also allows responding to inactivity of organs subject to ombudsman control.

- the Ombudsman is authorized to take action not only on request, but also ex officio, which in principle courts cannot do.

- In many countries, the scope of control covers not only legality, but also compliance with the principles of "good administration", "equity", justice, "efficiency of administrative operations", allows to counteract its "negligence" - here also the author writes about decision-making slack.

The Ombudsman is an ombudsman of universal nature, whose task is to protect the freedoms and rights of man and citizen, regardless of who this man is and regardless of the nature of freedom and rights. Other ombudsman institutions of a more specialized nature - have also appeared in Poland. These include the Ombudsman for Small and Medium-sized Enterprises.

Pursuant to the Act of 6 March 2018, the Ombudsman for Small and Medium-sized Enterprises (Act of 6 March 2018 on the Ombudsman for Small and Medium-sized Enterprises (Journal of Laws of 2018, item 648) was established. In accordance with art. 1 of this Act, he protects the rights of micro, small and medium-sized enterprises, in particular respect for the principle of freedom of economic activity, deepening the confidence of entrepreneurs in public authority, impartiality and equal treatment, sustainable development and the principle of fair competition and respect for decency and legitimate interests of entrepreneurs.

First of all, it should be noted that the Ombudsman for Small and Medium Enterprises is not a classic ombudsman. Closer to the executive ombudsman indicated above. It is not an independent body; there are also links between the Ombudsman and the executive. The lack of independence is evidenced by the method of appointing the Ombudsman (by the Prime Minister at the request of the minister competent for economy, the manner of appointing the Deputy (by the minister and not by the Ombudsman himself) and the procedure for establishing the Bureau Statute (the Ombudsman does not do this, and the minister competent for economy).

The Ombudsman for Small and Medium-sized Enterprises has a number of powers - they are broadly defined, e.g. in the sphere of administrative and court-administrative proceedings (e.g. requesting administrative proceedings, filing complaints and cassation complaints to the 
administrative court, as well as participating in these proceedings - on rights of the prosecutor). However, he does not have some of the Ombudsman's rights, e.g. he cannot demand that civil proceedings be instituted. If the Ombudsman for Small and Medium-sized Entrepreneurs deems it necessary to request the initiation of proceedings in civil matters, then he can apply to the Ombudsman for action by the latter.

Afairlysignificant difference between the classical Ombudsman (Rzecznik Praw Obywatelskich) and the Ombudsman for Small and Medium-sized Enterprises is due to the fact that the Ombudsman acts when human and civil liberties and rights are violated, and "cannot and should not get involved as a representative of the interests of individual social groups or political groups" [5, p. 42].

On the other hand, the Ombudsman for Small and Medium-sized Entrepreneurs protects "entrepreneurs' rights" by acting on the request of an individual entrepreneur (and taking individual legal measures, e.g. lodging a complaint), however the Act on the Ombudsman for Small and Mediumsized Enterprises indicates many provisions stating that the essence of the Ombudsman's activities is also upholds the interests of entrepreneurs: the Defender protects the "legitimate interests of entrepreneurs". The Defender gives opinions on draft normative acts regarding the interests of entrepreneurs; The Ombudsman, when undertaking actions, examines whether the entrepreneur's rights or interests have not been violated as a result of an act or omission of a public administration body.

It seems that the Act on the Ombudsman for Small and Medium-sized Entrepreneurs, using the concept of "entrepreneurs' interest" refers not only to the individual entrepreneur's interest, but also to the interests of group entrepreneurs, which is supported by the essence of some of the measures that the Ombudsman may use regarding protection rights of the entire group of entrepreneurs. And although the classical Ombudsman (Rzecznik Praw Obywatelskich) has similar powers, the justification for the Ombudsman's non-involvement as a representative of individual social groups is that there may be a violation of the rights of another group for which this Ombudsman does not plead (and which he is also called to defend). The classical Ombudsman (Rzecznik Praw Obywatelskich) is a universal protection body. Meanwhile, the Ombudsman for Small and Medium-sized Entrepreneurs is appointed as the Ombudsman of entrepreneurs - both individual and the whole group; is to act in the interest of this group.
The Ombudsman for Small and Medium-sized Entrepreneurs has no feature of independence; the classical Ombudsman (Rzecznik Praw Obywatelskich) is independent. As indicated above, the lack of independence is evidenced by the manner in which the Ombudsman for Small and Medium-sized Entrepreneurs was appointed, the manner in which his Deputy was appointed (by the minister and not by this Ombudsman himself) and the procedure for establishing the Statute of the Bureau (the Ombudsman and the minister do not). This is very important, because lack of independence may affect the actions of Ombudsman for Small and Mediumsized Entrepreneurs: he may, for example, refuse to undertake certain types of matters (when the Prime Minister so wishes); may refuse to lodge a specific type of legal remedy (e.g. complaints to the administrative court about tax decisions significantly burdening the recipient financially), etc.

The attribute of independence in the case of the Ombudsman contributed to his brand and position, and significantly influenced his perception and social perception. It seems that the Ombudsman for Small and Medium-sized Entrepreneurs will not have such a good brand; he will be associated with the executive branch. Given that the rights of entrepreneurs may be violated to the greatest extent by the executive, it is hard to resist the impression that the Ombudsman's actions can sometimes be illusory. Therefore, if any new ombudsman institutions are to be created, they should be fully independent. Creating an ombudsman dependent on the executive power significantly limits the possibilities of its operation.

Conclusions. The dominant thinking is that a greater number of ombudsman institutions contribute to the protection of human rights or the rights of a specific group of entities. The multiplication of ombudsman institutions raises questions abouttheirmutual relationship, the position of individual ombudsmen relative to each other (the "importance" of one ombudsman over another), the principles of cooperation / cooperation, etc. The establishment of a new ombudsman institution separate from the classical Ombudsman (Rzecznik Praw Obywatelskich) does not necessarily mean an increase in the protection of the rights of a given group, rather, it shows that there is a political will to enhance this group, or it is considered extremely important for social and economic life, etc., and at the same time there is a conviction that the rights of this group are frequently violated, or whether the situation of this group is considered worse than others groups. 


\section{References:}

1. Gadlin H. The Ombudsman:What's in a Name? Negotiation Journal, nr 16, styczeń 2000.

2. Kmieciak Z. Idea procedur administracyjnych trzeciej generacji (na przykładzie postępowania w sprawach dofinansowania projektów w ramach programów operacyjnych. Państwo i Prawo. z. 5/2015.

3. Reif L.C., The Ombudsman, Good Governance and the International Human Rights System, Dordrecht 2004,

4. Świątkiewicz J. W piętnastą rocznicę ustanowienie instytucji Rzecznika Praw Obywatelskich, w: Godność człowieka a prawa ekonomiczne i socjalne. Księga Jubileuszowa wydana w piętnastą rocznicę ustanowienia Rzecznika Praw Obywatelskich. Warszawa 2003.

5. Trociuk S. Komentarz do ustawy o Rzeczniku Praw Obywatelskich. Warszawa 2014.

6. Urbanowicz S. Kontrola sądowa nad działalnościa administracyjną. Palestra 1938, nr 5. 